\title{
An Analysis of Technical Efficiency in the Presence of Developments Toward Commercialization: Evidence from Tanzania's Milk Producers
}

\author{
Sirak Bahta ${ }^{1}$ (D) Amos Omore ${ }^{2}$ - Darek Baker ${ }^{3}$. Iheanacho Okike . $^{4}$ \\ Berhanu Gebremedhin $^{5}$. Francis Wanyoike ${ }^{1}$
}

Published online: 5 June 2020

(c) The Author(s) 2020

\begin{abstract}
The level and determinants of technical efficiency in milk-producing households are examined in connection with households' level of commercialization. A sample of 469 milk producers are modeled using Stochastic Frontier Analysis (SFA). Average Technical Efficiency (TE) is estimated to be $80 \%$, with variation among regions and generally reflecting levels of commercialization. Results show that assuming milk producers are rational, TE is increased by increasing the number of cattle, cows, and crossbreeds, and by additinal veterinary and feed inputs. These results support much existing research, and our contribution is the extension of analysis to actions and characteristics of the value chain due to commercial behaviors. We identify both direct and indirect potential effects of commercialization and identify mechanisms for their operation in development programs for commercial value chains. We find that credit access, training, group membership, market participation, and female household all improve TE while non-cattle income would reduce TE. We present sub-groups of households to better contrast levels of productivity and compare a limited number of the sub-groups' characteristics and actions. We provide commentary and explanation regarding commercialization and its direct and indirect connections to productivity. Recommendations include partnerships and facilitating actions that support commercialization, in association with improving efficiency in Tanzanian dairy.
\end{abstract}

Keywords Technical efficiency · Dairy farms - Dairy farm development $\cdot$ Stochastic production frontier - Tanzania

\section{Résumé}

Le niveau et les déterminants de l'efficacité technique dans les ménages producteurs de lait sont étudiés par rapport au niveau de commercialisation des ménages. Un

Sirak Bahta

s.bahta@cgiar.org

Extended author information available on the last page of the article

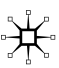


échantillon de 469 producteurs de lait est modélisé à l'aide d'une analyse de frontière stochastique (AFS). L'efficacité technique moyenne (ET) est estimée à 80\%, avec des variations entre les régions, et elle reflète généralement le niveau de commercialisation. Les résultats montrent que, si l'on part du principe que les producteurs de lait sont rationnels, l'ET augmente lorsque le nombre de bovins, de vaches et de croisés augmente, ainsi que lorsqu'on ajoute des intrants vétérinaires et alimentaires en plus. Ces résultats viennent appuyer une grande partie de la recherche existante, et nous contribuons en élargissant l'analyse aux actions et aux caractéristiques de la chaîne de valeur liées aux comportements commerciaux. Nous identifions les effets potentiels à la fois directs et indirects de la commercialisation et identifions des mécanismes pour leur fonctionnement dans les programmes de développement des chaînes de valeur commerciales. Nous constatons que l'accès au crédit, la formation, l'appartenance à un groupe, la participation aux marchés et le fait d'être un ménage composé de femmes sont tous des facteurs qui améliorent l'ET tandis que les revenus non bovins réduiraient l'ET. Nous présentons des sous-groupes de ménages pour mieux comparer les niveaux de productivité et nous comparons un nombre limité de caractéristiques et d'actions des sous-groupes. Nous fournissons des commentaires et des explications à propos de la commercialisation et des liens directs et indirects avec la productivité. Les recommandations incluent de nouer des partenariats et de mettre en place des actions qui facilitent la commercialisation, tout en améliorant l'efficacité dans l'industrie laitière en Tanzanie.

\section{Introduction}

In many developing countries, dairy provides a regular income, as well as an affordable source of protein. Economic growth and urbanization have fueled demand for animal products (Delgado et al. 1999; FAO 2019). Thus dairy faces a growing market in developing countries and is often associated with "pro-poor growth" (Ravallion and Chen 2003) and a candidate for value chain development action (Swinnen and Maertens 2007; Springer-Heinz 2018, p. 4). Dairy is a rapidly growing industry in Tanzania, and smallholders dominate production. Smallholders' milk is thought to primarily be consumed on-farm or sold within communities (Makoni et al. 2013). Variations in the volumes and shares of smallholder production that are sold through the informal market are known to occur across regions and between seasons, but some $90 \%$ followed this channel at the last national-level review (National Bureau of Statistics 2003). A more recent study by Niras (2010) estimates that some $98 \%$ of milk is produced in "traditional" farming systems and that $67.5 \%$ of the milk is marketed through informal market channels to urban and peri-urban areas. The formal processing sector handles about 3\% of national production (Makoni et al. 2013).

Maintaining and growing the dairy industry in Tanzania requires milk in higher volumes, and dairy cow productivity is vital in this endeavor. Constraints on the development of the Tanzanian dairy industry do, however, extend into numerous spheres. They have been summarized (Shapiro 2017) as being due to, among other things, poor animal nutrition, breeding and health, inadequate financial and credit facilities, poorly organized milk collection and distribution, 
scarce processing milk handling facilities, difficulties in securing milk supply, and inadequate support services. Research work with Tanzanian dairy specifically on constraints identified land, water, and labor as fundamental constraints (Baker et al. 2015), and this reinforced the importance of improved dairy productivity in Tanzania.

Meeting the changing needs of poor milk producing households is increasingly associated with commercialization. Commercialization is usually defined as a form of organization around production that is targeted at markets, rather than sales of an unplanned or episodic surplus over subsistence needs (Pingali and Rosegrant 1995; Pingali 1997). In practical terms, it relates to producers' orientation to, access to, and utilization of product and input markets (Gebremedhin and Jaleta 2010). Although, in general, commercialization might be viewed as an alternative to subsistence production, much development effort centers on achieving a transition between these two states (von Braun 1995). A broader view of commercialization might extend to off-farm income as a source of funds for inputs, and to a reorganization of the smallholder household in line with skills and commercial predispositions.

The effect of the scale of operation on milk-producing households' welfare remains unclear: Gelan and Muriithi (2015) identified no scale-related benefits to producers from increasing herd size, while Twine and Katjiuongua (2015) project substantial aggregate social benefit from scale effects. For Tanzanian dairy, there are interactions between scale, milk volume, and marketing (more milk produced throughout the year attracts buyers' attention), and scale of operation reduces recurrent and fixed costs per unit of milk. A potentially virtuous circle can operate where the resulting higher margins generate cash for the purchase of inputs and longer-term investment, such as genetic improvement: these, in turn, boost productivity. Group action by farmers in East African dairy settings mimics scale effects to reduce unit costs (including transaction costs) and facilitate technology uptake and training (Rao et al. 2016) but do not necessarily facilitate commercial linkages to producers nor increased productivity (Omondi et al. 2017).

The current study identifies the influences on milk-producing farms dairy productivity as a guide to more effective investment in dairy development. It employs data from a random sample of milk-producing households across a spectrum spanning pre-commercial through to commercial production in four districts of Tanzania's Morogoro and Tanga regions. Stochastic Frontier Analysis (SFA) is used to derive a statistical measure of technical efficiency (a "frontier") and identify efficiency drivers. The frontier represents a best case, and points lying within the frontier reveal their inefficiencies as a "distance" within the frontier (Otieno et al. 2012; Bahta et al. 2015). Investigation of the determinants of technical efficiency then enables policy advocacy for approaches to enhance dairy production efficiency and inform investments in Tanzanian dairy production and value chains. In particular, we identify relationships between commercial behavior and its precursors and efficiency.

The current paper contributes to the understanding of the nature and role of commercialization in productivity and pro-poor development. Subsequent parts of the paper are organized as follows: "Materials and Methods" section describes the methodological approach, which includes the empirical estimation followed in the study and the descriptive analysis of the study area and data. "Results and Discussion" 
section discusses the results, and "Conclusion and Recommendations" section offers conclusions.

\section{Materials and Methods}

\section{Empirical Measurement and Analysis of Efficiency}

Measurement of farmers' technical efficiency has long been a research preoccupation with agricultural economists. Commonly, empirical results indicate that large proportions of sample farms fall well within the efficient frontier locus (Laha 2014). Such measurement of efficiency requires estimation of an efficient production function, and this can be achieved by non-parametric and parametric methods (Latruffe 2010).

The non-parametric approach uses mathematical programming techniques, of which the most widely used is data envelopment analysis (DEA) (Mester 2003). DEA has the desirable empirical property of imposing neither a specified functional form nor assumptions about the nature of the residual terms from regression analysis (Tran 2009). However, its limitations include non-inclusion of prices, which means that it accounts only for technical inefficiency in the form of excessive inputs use or producing too few outputs (Mester 2003). DEA is also limited by its implicit assumption of the absence of random errors. It uses a two-stage estimation procedure where the production (or profit) function is estimated to derive efficiency scores as the first stage. In the second stage, the derived efficiency scores are used as explanatory variables in a profit function to be estimated econometrically. Further, DEA ignores a management-related issue in that the firm's input choices are potentially affected by that firm's knowledge of its current level of technical efficiency (Chirwa 2007). Wang and Schmidt (2002) extend this reasoning in a critique of the two-stage estimation process. Parametric analysis of efficiency uses econometric techniques to estimate a frontier function. SFA (Aigner et al. 1977) is the most commonly used parametric approach, and it requires the specification of a functional form for the frontier production function.

The primary point of difference between the two approaches lies in the nature of the assumptions made in identifying the frontier, and the assumptions about distributions of the error terms (Hyuha 2006). The trade-off between using SFA and DEA relates then to the consideration of biases arising from errors in specification on one hand and measurement on the other (Erkoc 2012). In the context of developing countries, SFA is prominent due to its accommodation of data quality and accuracy issues provided that misspecification is not serious (Coelli 1995). Hence, the major advantage of SFA lies in its (single step) estimation procedure and its accommodation of measurement error and other noise in the data (Kolawole 2006).

SFA entails the simultaneous estimation of the frontier production function and an inefficiency model. Usefully, inefficiency effects are specified as a function of other variables (Chirwa 2007). It effectively specifies the relationship between output and input levels and decomposes the error term into separate components representing random errors and inefficiency. By taking into account some management 
and policy-relevant variables on both the internal (farm management) and external (value chain and service) environments, the current study addresses steps toward commercialization.

The stochastic production frontier analysis begins with specifying a log-linear production function as follows:

$$
\begin{gathered}
Y_{i}=\alpha+x_{i}^{\prime} \beta+\varepsilon_{i} \\
\varepsilon_{i}=v_{i}-u_{i}
\end{gathered}
$$

where $Y_{i}$ represents the natural logarithm of the observed output of the $i$ th household, $x_{i}$ is a vector of the natural logarithms of the $\mathrm{N}$ inputs for the $i$ th household, and $\beta$ is a vector of unknown parameters. The error term $\varepsilon_{i}$ has two components, $u_{i}$ and $v_{i} . u_{i}$ is a non-negative random variable measuring inefficiency, and $v_{i}$ is a stochastic disturbance term assumed to be independently and identically distributed as $N\left(0, \sigma_{v}^{2}\right)$ across observations.

The probability density of $Y_{i}$ in Eq. (1) is revealed by computing the joint density of $\varepsilon_{i}$. Following Greene (2008),

$$
f_{\varepsilon, u}\left(\varepsilon_{i}, u_{i}\right)=f_{u}\left(u_{i}\right) f_{v}\left(\varepsilon_{i}+u_{i}\right)
$$

Integrating Eq. (3) with respect to $u_{i}$ then gives the marginal density of $\varepsilon_{i}$. This measures the contribution of observation $i$ to the log-likelihood (ibid).

$$
\ln L_{i}\left(\alpha, \beta, \sigma_{v}^{2}, \sigma_{u}^{2} \mid Y_{i}, X_{i}\right)=\ln f_{\varepsilon}\left(Y_{i}-\alpha-\beta X_{i} \alpha, \beta \mid \sigma_{v}^{2}, \sigma_{u}^{2}\right)
$$

The random variable, which is also the inefficiency term $u_{i}$, can take a variety of distributions: exponential (Meeusen and van den Broeck 1977), half-normal (Aigner et al. 1977), truncated-normal (Stevenson 1980) as well as gamma (Greene 2003). The half-normal distribution is the most commonly used specification in cross-section studies such as ours (Coelli 1995; Bravo-Ureta and Pinheiro 1993; Bauer 1990). Hence, we assume that $u_{i}$ in Eq. (4) is independently half normally $N^{+}\left(\mu_{i}, \sigma_{u}^{2}\right)$ distributed. Logic then enables heteroscedasticity in $u_{i}$ to be modeled as a function of explanatory variables that may cause inefficiency. Such variables are introduced as follows (Kumbhakar and Hjalmarsson 1991; Huang and Liu 1994):

$$
\mu_{i}=z_{i}^{\prime} \eta
$$

where $\mu_{i}$ is the mean of a pre-truncated inefficiency distribution, $z_{i}$ is a vector of household-specific explanatory variables that affect household-level inefficiency, and $\eta$ is an unknown vector of coefficients to be estimated.

The estimable log-likelihood half-normal specification, with the required heterogeneity in the inefficiency term, will have the following form (Greene 2008): 


$$
\begin{aligned}
\ln L(\alpha, \beta, \sigma, \lambda, \eta)= & -N\left[\ln \sigma+\frac{1}{2} \ln 2 \pi+\ln \Phi\left(\mu_{i} / \sigma_{u}\right)\right] \\
& +\sum_{i=1}^{N}\left[-\frac{1}{2}\left(\frac{\varepsilon_{i}+\mu_{i}}{\sigma}\right)^{2}+\ln \Phi\left(\frac{\mu_{i}}{\sigma \lambda}-\frac{\varepsilon_{i} \lambda}{\sigma}\right)\right]^{\prime}
\end{aligned}
$$

where $\lambda=\sigma_{u} / \sigma_{v}, \sigma^{2}=\sigma_{u}^{2}+\sigma_{v}^{2}, \sigma_{u}=\lambda \sigma / \sqrt{1+\lambda^{2}}$, and $\varepsilon_{i}=Y_{i}-\alpha-x_{i}^{\prime} \beta$.

The log-likelihood function in Eq. (6) can then be estimated using Stata (Stata Inc. 2013).

Finally, the technical efficiency (TE) of an individual household can be calculated using the following formula (Jondrow et al. 1982):

$$
T E_{i}=E\left\{\exp \left(-u_{i}\right) \mid \varepsilon_{i}\right\}=E\left\{\frac{1-\Phi\left(\sigma_{*}-\mu_{* i} \sigma_{*}\right)}{1-\Phi\left(-\mu_{* i /} \sigma_{*}\right)}\right\} \exp \left(-\mu_{* i}+\frac{1}{2} \sigma_{*}^{2}\right)
$$

where $\mu_{* i}=\varepsilon_{i} \sigma_{u}^{2} / \sigma^{2}$ and $\sigma_{*}^{2}=\sigma_{u}^{2} \sigma_{v}^{2} / \sigma^{2}$

Within this framework, the TE of farms ranges from 0 to 1 . Best practice farms score close to 1 , and the least efficient close to zero.

\section{Empirical Model}

Although the Cobb-Douglas production function follows some restrictive assumptions such as perfect competition in the factor and product markets and constant return to scale (Murthy 2002), the study adopted the functional form after testing for appropriate functional form. ${ }^{1}$ Following Russell and Young (1993), we also assume that functional specification has a discernable but rather small impact on efficiency.

Thus, we employ the semi-log-linear Cobb-Douglas production function as the empirical version of the stochastic frontier production model. Among other useful and convenient properties, this functional form allows direct derivation and interpretation of coefficients as elasticities.

The production function model is specified as follows:

$$
\ln \operatorname{TOTM}_{i}=\beta_{0}+\beta_{1} x_{i}+\cdots+\beta_{n} x_{n}+\varepsilon_{i}
$$

where $\mathrm{TOTM}_{i}$ is total annual milk production by the $i$ th household during the year 2013 production season ${ }^{2}$ in liters; $x_{n}$ is the natural logarithm of each of $\mathrm{N}$ inputs (total cattle, and the number of cows, as measures of scale of operation, percent of cattle that are crossbred as a measure of innovation behavior, as well as input use such as veterinary expenses and feed expenses) considered for the model. $\beta_{i}$ are

\footnotetext{
1 The test of multicollinearity shows the presence of high multicollinearity between the interaction and independent variables. (As a rule of thumb, a variable whose VIF values are greater than 10 may merit further investigation. Tolerance, defined as $1 / \mathrm{VIF}$, is used by many researchers to check on the degree of collinearity (STATA Web books 2013)).

2 The survey was conducted from Dec 2013 to February 2014.
} 
unknown coefficients to be estimated and $\varepsilon_{i}$ is the compound error term specified in Eq. (2).

The following model (Eq. 9) is specified to capture the possible effects of the exogenous variables that affect technical inefficiency.

$$
\mu_{i}=\eta_{0}+\eta_{1} z_{1} \ldots \eta_{n} z_{n}+\omega_{i}
$$

where $\eta_{i}$ are unknown coefficients of the inefficiency effect to be estimated corresponding to each exogenous variable $z_{n}$, and $\omega_{i}$ is a stochastic error term that captures the effect of unaccounted-for household-specific variables. The exogenous variables considered for model 1 include indicators of commercial behavior such as credit use, capacity for purchasing — as opposed to producing - additional inputs by utilizing non-cattle income, marketing group membership for inputs and outputs, use of female labor, and participation in training. In model 2, we have introduced a commercialization indicator, market participation variable as motivated in Tirkaso and Hess (2018). Following Wang and Schmidt (2002), Eqs. (8) and (9) are estimated simultaneously.

\section{Data and Descriptive Analysis}

\section{Data and Study Area}

This paper uses farm-level cross-sectional survey data collected under the auspices of a research project that tested dairy interventions. ${ }^{3}$ The project assembled detailed information on costs of and returns to livestock production, along with selected technical, physical, demographic, and value chain-related variables for farm household operations across groups representing different farm types.

The survey was undertaken in two milk-producing regions of Tanzania-Morogoro, and Tanga - in 2012 and 2013. The specific study sites (Mvomero and Kilosa in Morogoro and Handeni and Lushoto in Tanga) provided suitable variation in the level of commercialization, with selection based on spatial maps' overlays ${ }^{4}$ of socio-economic data (human population and poverty, consumption levels, and market access), livestock density and profile (\% of herd held as milking cows, numbers of exotic breeds), and types of livestock production (particularly investment in improved feeding and animal health) and marketing (such as marketing group membership) system types (Fig. 1).

\footnotetext{
3 The More Milk in Tanzania project seeks to improve rural-based livelihoods through dairy production. See https://maziwazaidi.org/.

4 The overlays defined sites ranging from extensive/pre-commercial rural producers who predominantly own zebu cattle and sell milk to rural consumers (R-to-R), to relatively more intensive/more commercial rural producers who have relatively more improved dairy genes in their herds and predominantly sell milk to urban consumers (R-to-U), usually via bulk traders (Table 1). These strata also represent a gradient of increasing intensification. Two districts were then selected in each region, one R-to- $\mathrm{R}$ and the other R-to-U. For Morogoro, Kilosa and Mvomero districts were selected to represent R-to-R and R-to-U, respectively. Similarly, Handeni and Lushoto districts represent R-to-R and R-to-U, respectively, for the Tanga region.
}

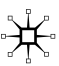




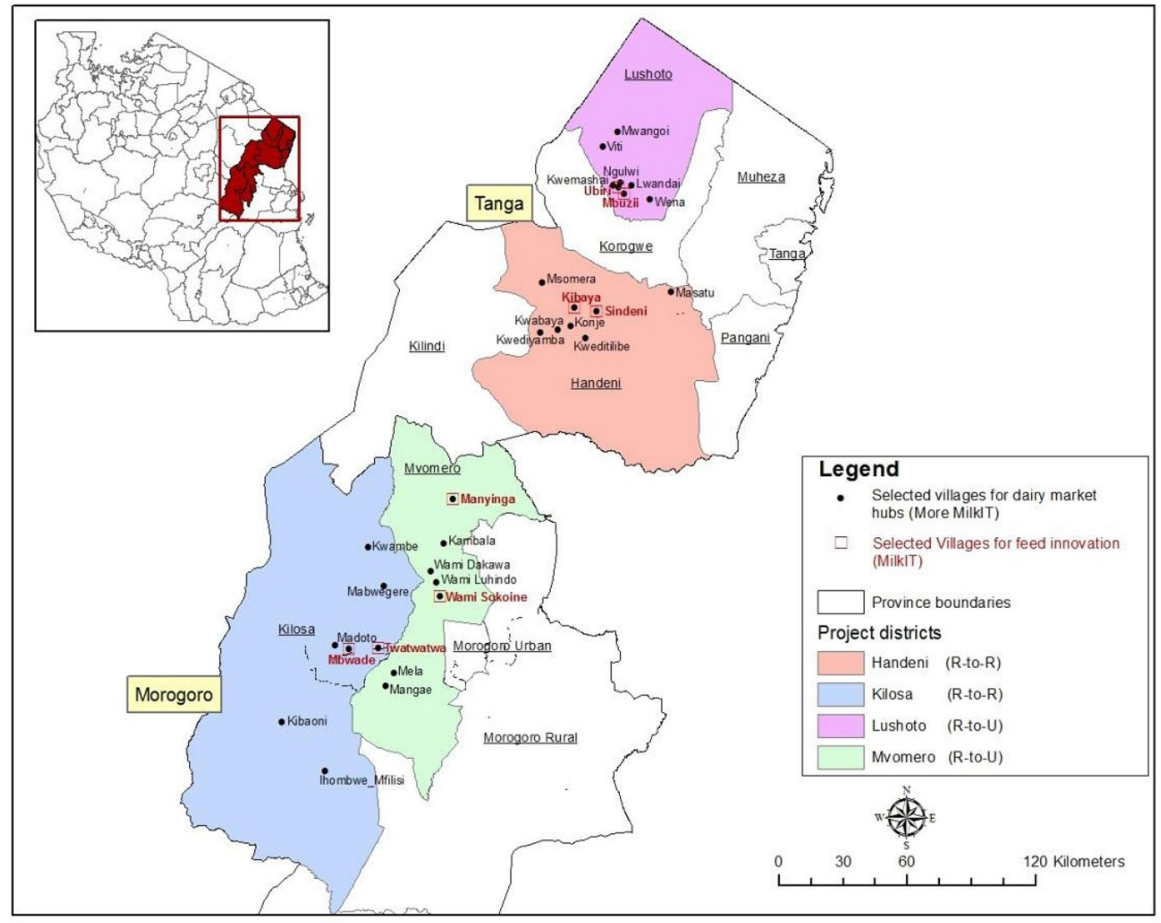

Fig. 1 Map of selected field sites in Tanzania indicating the locations of selected villages for piloting dairy market hubs. Key: R-to-R: Rural production to rural consumption (pre-commercial), R-to-U: Rural production to urban consumption (more commercial)

The Mvomero district which comprises four divisions (Turiani, Mvomero, Mlali, and Mgeta) and has a total cattle population of 187,350, of which 5\% (9314 cows) are of improved dairy genetic makeup. Agro-pastoralists keep the majority of the remaining 178,036 indigenous cattle in extensive systems. Kilosa district has a total cattle population of 215,100 of just which $1 \%$ (2405) is improved dairy. Similarly, in Mvomero, the majority of the 210,627 indigenous cattle are kept by agro-pastoralists, including the Maasai ethnic group.

For the Tanga region, the Handeni district area is mainly inhabited by the ethnic Zigua tribe who are both arable farmers and sedentary livestock keepers. The total cattle population is 126,780, of which $1 \%$ (1045) are improved dairy. Again, the majority of the 124,735 indigenous cattle are kept by agro-pastoralists in extensive systems. Finally, the Lushoto district which is situated in the northern part of Tanga at the foot of the western Usambara Mountains. Lushoto has 119,492 cattle, of which $24 \%(29,200)$ are improved cattle. Lushoto's improved cattle are found mostly in the highland areas where $65 \%$ of households own cattle. 
Table 1 Descriptive statistics of sample characteristics

\begin{tabular}{|c|c|c|c|c|c|}
\hline Variable & $N$ & Min & Max & Mean & SD \\
\hline Household size (no.) & 469 & 1 & 20 & 7.1 & 3.3 \\
\hline Size of cropland (acres) & 468 & 0 & 300 & 16.2 & 26 \\
\hline Total cattle (no.) & 469 & 5 & 1600 & 34.6 & 91.9 \\
\hline Crossbred cattle in herd (\%) & 469 & 0 & 100 & 19.1 & 38.3 \\
\hline Cows (no.) & 469 & 2 & 500 & 12.8 & 31.5 \\
\hline Cows proportion (\%) & 469 & 15 & 100 & 40.1 & 16.23 \\
\hline AI expenditure (Shillings) & 469 & 0 & 20,000 & 606.6 & 2002 \\
\hline Deworming expenditure (Shillings) & 469 & 0 & $1,200,000$ & $34,812.8$ & 98,398 \\
\hline De-ticking expenditure (Shillings) & 469 & 0 & $24,000,000$ & $167,106.4$ & $1,176,767$ \\
\hline Vaccination expenditure (Shillings) & 469 & 0 & $3,000,000$ & $27,895.7$ & $213,824.1$ \\
\hline Treatment expenditure (Shillings) & 469 & 0 & $10,000,000$ & $123,800.1$ & $627,769.1$ \\
\hline $\begin{array}{l}\text { Total veterinary and breeding expenditure (Shil- } \\
\text { lings) }\end{array}$ & 469 & 0 & $34,500,000$ & $354,221.6$ & $1,755,631$ \\
\hline Size of improved pasture (acres) & 469 & 0 & 50 & 2.2 & 7.8 \\
\hline Total expenditure on feed (Shillings) & 469 & 0 & $5,000,000$ & $35,090.8$ & $252,298.4$ \\
\hline Household labor (h/year) & 469 & 0 & 100.25 & 90.5 & 92 \\
\hline Hired labor (h/year) & 469 & 0 & 18.9 & 9.0 & 27.8 \\
\hline Female household labor (h/year) & 469 & 0 & 100 & 42.2 & 38.8 \\
\hline Male household labor (h/year) & 469 & 0 & 100 & 57.8 & 38.8 \\
\hline Estimated milk production (litres/year) & 469 & 73 & 4560 & 575.9 & 555.2 \\
\hline Commercialization index & 469 & 0 & 1 & 0.296 & 0.347 \\
\hline Market participation $(1=$ sellers, $0=$ non-sellers $)$ & 469 & 0 & 1 & 0.48 & 0.50 \\
\hline Distance to delivery point $(\mathrm{km})$ & 217 & 0 & 25 & 1.45 & 3.3 \\
\hline Income from non-cattle sources (Shillings) & 469 & 0 & 841,560 & $4,140,560$ & $39,589,226$ \\
\hline
\end{tabular}

Source Authors computation, *Exchange rate $1 \mathrm{USD}=1589.2845$ TZS (Exchange Rates, December 2013)

\section{Descriptive Analysis}

Table 1 presents selected farm household characteristics of the sample of 469 households used for the current study. These characteristics reflect the substantial variation in the factors likely to affect productivity, as well as in elements of commercialization.

The sample's typical milk-producing farm household has about 7.1 persons (minimum is one person, and maximum is 20 person per household), which is slightly higher than the national average of about 6 (Katjiuongua and Nelgen 2014), and owns about 16 acres of cropland, of which 2.2 acres are used for growing improved pasture. The maximum land size and pasture land observed are 300 ha and 50 ha, respectively.

Our average farm household owns 35 cattle, of which about 40\% (12.7 in number) are cows, and $19 \%$ are crossbred. The ownership of cattle and breed composition ranges are from 5-1600 to $0-100 \%$, respectively. These cows, on average 12.7 per 
household, produce annually about $576 \mathrm{~L}$ of milk of which some is sold and delivered to a buyer or milk collection point, situated on average about $1.45 \mathrm{~km}$ away.

The average commercialization index, calculated as the ratio of total milk sales (fresh and fermented) to the total milk production, is $30 \%$. This indicates that, on average, about $30 \%$ of the milk produced is sold to both formal and informal markets. Table 1 also shows only about $48 \%$ of the milk producers are market participants or have a commercialization index of more than zero.

The average total veterinary and breeding expenditure is 354,221 Tanzanian Shillings (TZS) (222.8 USD), of which de-ticking followed by treatment expenditures is the largest item. The average cost for artificial insemination (AI) services is about 606.6 TZS, while the feed costs that milk producers in the study area incur is on average, 35,090.8 TZS. The maximum total veterinary and breeding expenditure is 34,500,000 TZS.

Table 1 also shows that most farm work is conducted by family labor. A typical milk producer farm household in the study area works about $90 \mathrm{~h}$ per week and uses hired labor only for about one day $(9 \mathrm{~h})$ per week. The male household members work on the farm on average for $57.8 \mathrm{~h}$ per week and female household members $42.2 \mathrm{~h}$ per week. Some members of the farm household also engage in non-cattle activities and earn, together as a household, on average, about 4,140,560 TZS (2605 USD) per annum.

\section{Results and Discussion}

\section{Production Function Estimates}

Results from the SFA are shown in Table 2. The estimated value of $\gamma$ for both models (gamma $=0.011$ and gamma $=0.018$, for models 1 and 2 , respectively) allows us to reject the hypothesis (H0: $\gamma=0)$ of no significant technical inefficiency among Tanzanian milk producers. We also observe that the variation in technical inefficiency among milk producers in Tanzania occurs due to both farmer inefficiency and exogenous factors outside the farmers' control, rather than from random variation.

The strong statistical significance of Sigma-squared $\left(\sigma^{2}\right)$ on both models indicates that our technical efficiency analysis can explain the differences between farms' technical efficiency and the technical efficiency locus (points on the frontier). Moreover, the significance of $\sigma^{2}$ confirms that the frontier model is stochastic rather than deterministic.

As shown in Table 2, the LR test ${ }^{5}$ for models 1 and 2 are 15.2 and 24.6, respectively, with $p<0.05$. We thus fail to reject the null hypothesis that the SFA model

\footnotetext{
${ }^{5}$ Following Battese et al. (2004), the LR test is calculated as LR $=-2($ LFF-LLF1)), where LLF1 is the value of log-likelihood for the full Stochastic frontier that assumes the presence of inefficiency and LLF0 is the value of log-likelihood for OLS that assumes no presence of inefficiency. The degree of freedom equals $(\mathrm{k}=\delta+1)$, where $\delta$ is the number of explanatory variables in the inefficiency model of the stochastic frontier analysis.
} 
Table 2 Results of the stochastic frontier analysis

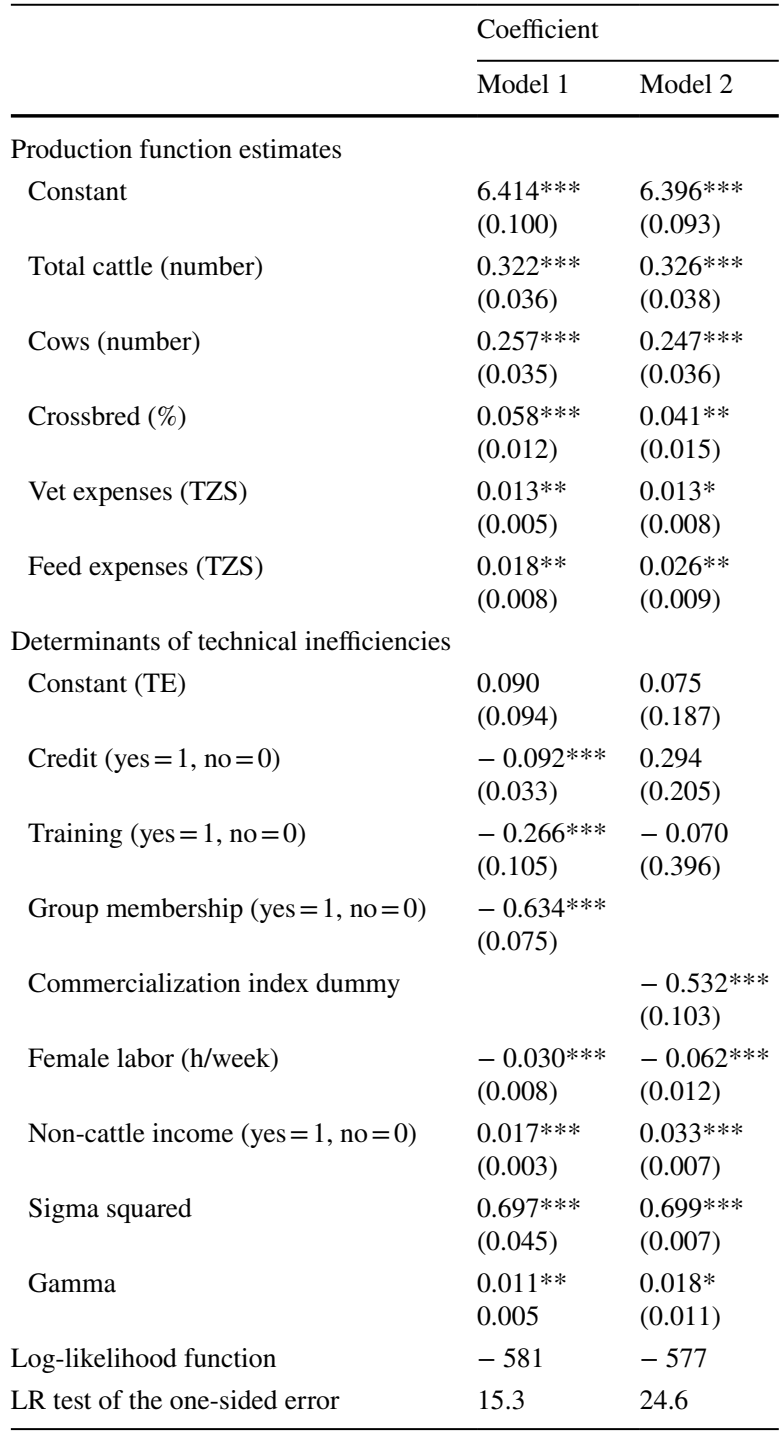

Corresponding standard errors are shown in parentheses. Source: Authors computation

Statistical significance levels: ***1\%;**5\%; *10\%

provides a better specification of the sample data than does our model. This test draws on Table 1 of Kodde and Palm (1986) for a comparison of critical values with the degree of freedom equal to $7(k=\delta+1)$. Thus, the null hypothesis is firmly rejected, leading to the acceptance of the full model, which incorporates production inefficiency effects and extends to variables associated with the observed range of commercialization. 
All the estimated coefficients for first-order explanatory variables (mostly input variables) have positive signs. They are statistically significant in both models (Table 2), suggesting that increased usage of these inputs would yield more output as postulated by theory and assuming that producers are rational (Coelli et al. 2005). That is, an increase in the number of cattle (a scale effect), cows and crossbreeds (indicators of commercialization), and additional veterinary and feed input usage (commercial behavior), increase productivity until the stage of diminishing marginal returns where marginal output starts to decrease with every additional unit of the inputs.

\section{Determinants of Technical Efficiency}

Table 2 presents the determinants of technical inefficiency. It should be noted that in the stochastic frontier estimation, the parameter for inefficiency level usually enters the inefficiency effects component of the model (second stage) as the dependent variable. Therefore, a negative sign on the coefficient variable is interpreted as a positive influence on efficiency (i.e., a reduction in inefficiency). Conversely, a positive coefficient is interpreted as a negative influence on efficiency (an increase in inefficiency) (Brummer and Loy 2000; Coelli et al. 2005).

Results for the estimated inefficiency effects in the stochastic frontier of both models show (see the lower part of Table 2) that many of the technical inefficiency explanatory variables are statistically significant and have the expected signs, except for non-cattle income. Hence training (Model 1) as well as commercialization index (as shown in Model 2) and other indicators of commercialization such as credit access and group membership (model 1) and use of female household labor (a commercial venture as outlined below, on both models) would significantly improve efficiency (reduce inefficiency). In contrast, increases in non-cattle income would reduce efficiency (increase inefficiency).

The finding that access to credit positively influences technical efficiency (model 1) is intuitively linked to the utilization of agricultural inputs and supports earlier results from Brummer and Loy (2000) and Obwona (2000). Group membership, a form of collective action, is likely to reduce transaction costs and hence enhance market access. Gyau et al. (2014) argue on this and extended to include group activities such as training in production methods, negotiation skills, product grading, and sorting and group dynamics, which subsequently enhance bulk marketing of products by members, exploit economies of scale. The effect on efficiency is confirmed in Table 2, which reveals that milk producers that are a member of a group or organization are technically more efficient than those who are not. This finding is in line with Twine et al. (2019), which shows group membership increases the probability of borrowing and the number of funds borrowed by milk-producing households in Tanzania. The group membership variable is highly correlated with the commercialization index dummy variable; hence it was dropped in model 2. Since many of the households $(>50 \%)$ have zero commercialization index (Table 1), following (Tirkaso. and 


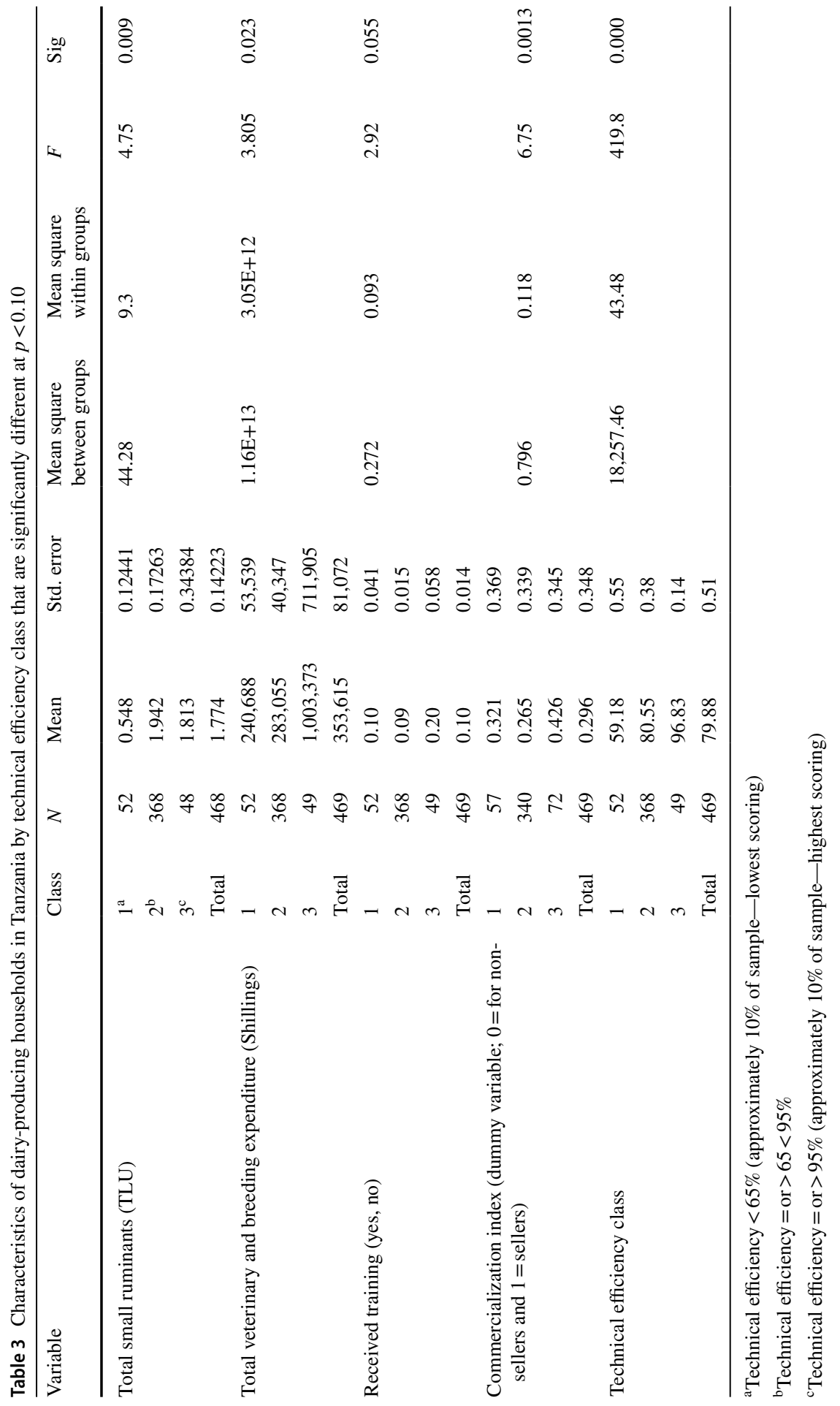

站 
Hess 2018) a dummy variable for market participation $(1=$ sellers, $0=$ non-sellers $)$ is used. The result in Model 2 can be interpreted as those milk producers who are highly commercially oriented, sell some of their milk output, are technically more efficient than those who do not sell or non-participants. Further examination of the commercialization variable (Table 3) confirms that about $29.6 \%$ of the milk sellers or market participants scored more than $95 \%$ technical efficiency. A closer look at the technical efficiency scores of milk sellers and non-sellers also (Fig. 2) shows that a more significant proportion of sellers scored more than $80 \%$ technical efficiency. In comparison, a significant proportion of the non-sellers have a technical efficiency in the rage of 55-80\%. The finding suggests the importance of increasing milk market participation by farmers in order to improve productivity, supporting the argument that commercialization improves farms' productivity by increasing their income and access to healthy and nutritious food (Pingali and Rosegrant 1995). Our finding is consistent with existing literature; for example, Tirkaso and Hess (2018) found that farmers with a higher degree of commercialization were technically more efficient compared to those with lower market participation.

Farmers' training is also found to be a significant factor (Model 1) affecting technical efficiency. Examination of the data confirms that more than $88 \%$ of the farmers who received training scored more than $65 \%$ technical efficiency (Table 3). Despite women spending less of their labor time on animal production and husbandry than do men, the results in Table 2 showed that the time spent by female household labor is a determining factor of technical efficiency in milk producing farms. This finding is in line with Covarrubias et al. (2012), who found that women's participation in livestock activities in Tanzania tends to be associated with selling milk.

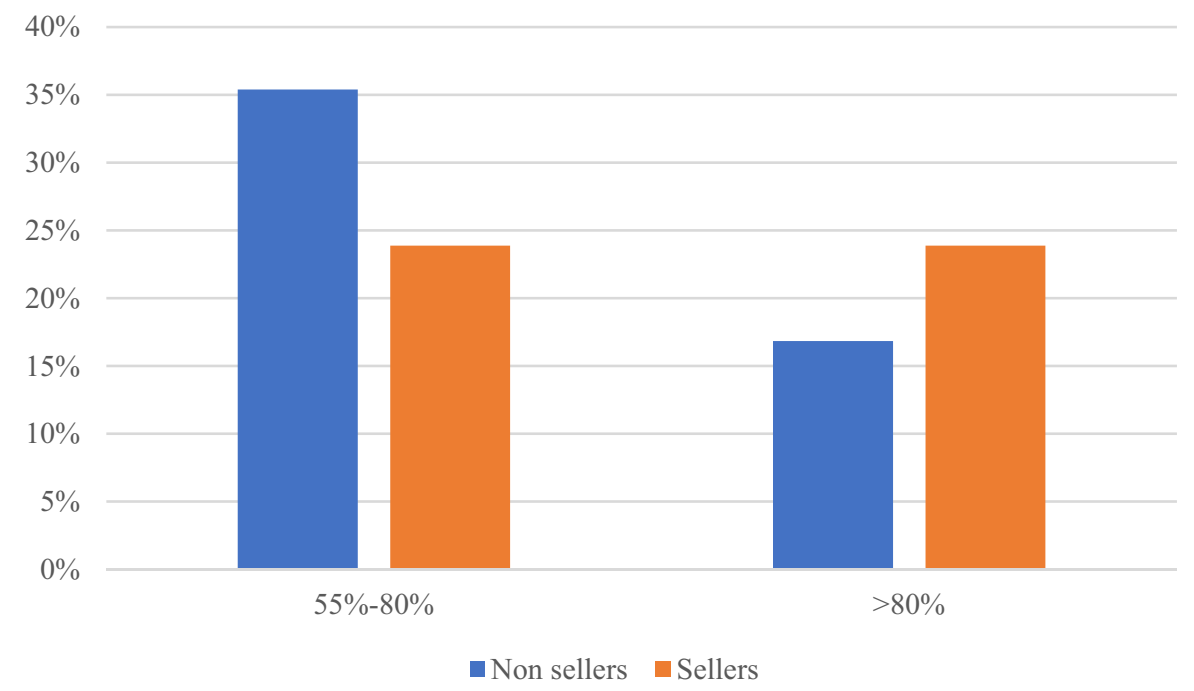

Fig. 2 Technical efficiency category (55-80\% and greater than $80 \%)$ of milk sellers and non-sellers 


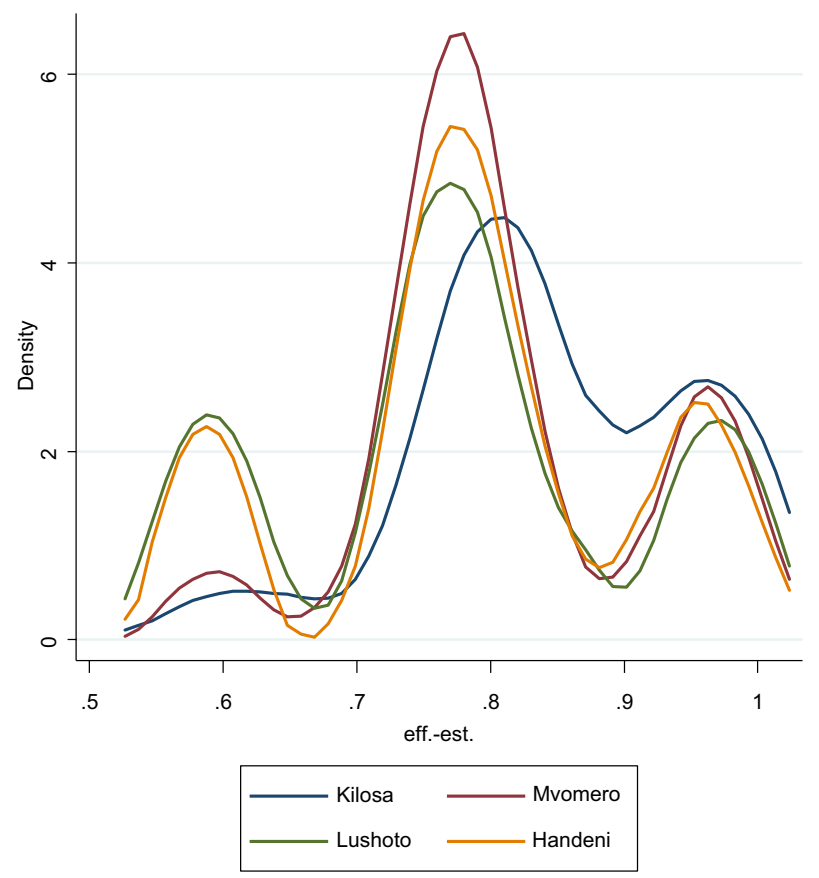

Fig. 3 Kernel density of technical efficiency scores by Districts

Further, consistent with this finding, a baseline study of 634 cattle-keeping households in Tanzania (Katjiuongua and Nelgen 2014) ${ }^{6}$ Showed that women report more significant participation in the sale of milk than do men, and allocate more labor to selling milk than do men in Kilosa, Handeni, and Mvomero districts.

Non-cattle income, which includes off-farm income, has a detrimental impact on the technical efficiency of milk-producing households in Tanzania. It was expected that spending time off the farm might improve farmer's production and management capability through the acquisition of information and knowledge, and hence positively influence farm performance (Bahta and Malope 2014). Further, off-farm work can assist in accumulating capital, which, when invested on the farm, can increase efficiency.

Otieno et al. (2012) and Bahta and Malope (2014) found a positive relationship between off-farm income and efficiency, and argue that this is evidence of re-investment of off-farm earnings into farm production, as a commercial venture. Perhaps in the case of milk producers of Tanzania, the unexpected influence of non-cattle income on efficiency might be attributed to, as noted by Rakipova et al. (2003) and Bahta et al. (2015), the time spent doing off-farm work which reduces time spent on efficiency-improving managerial activities.

Figure 3 and 4 shows the kernel density distribution of the technical efficiency by district and for all sample, respectively.

\footnotetext{
6 The situational analysis in this study used the same data as the current study.
} 


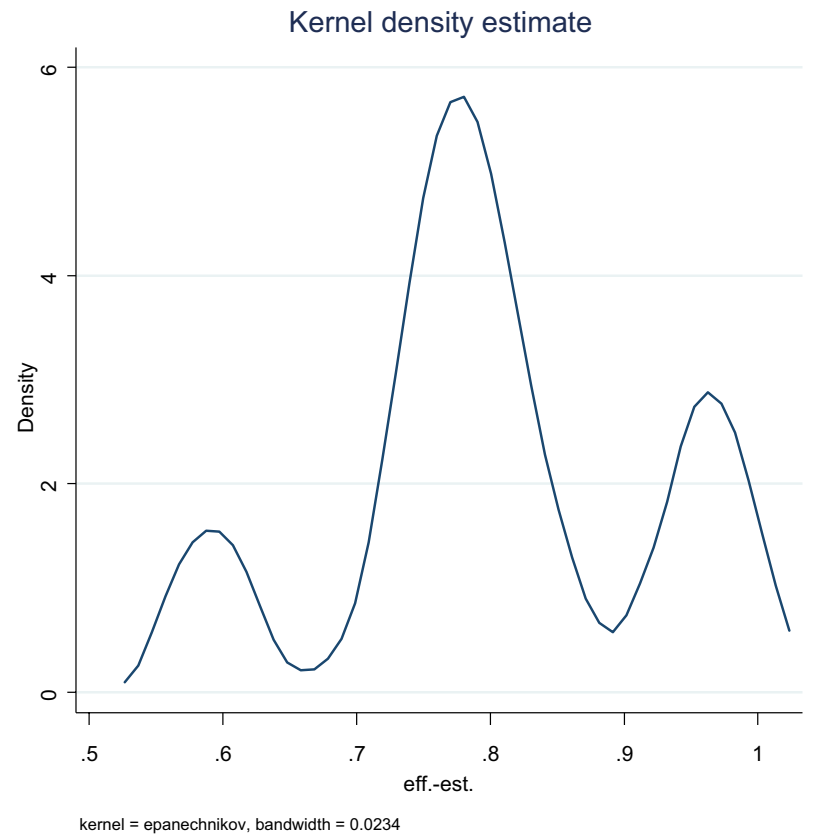

Fig. 4 Kernel density of technical efficiency, overall average TE $=80 \%$

In general, milk-producing farms in Kilosa are more technically efficient than a farm in other districts. This also implies that milk-producing farms in Kilosa are relatively more homogeneous than are other subsamples. Figures 5, 6, 7, and 8 show the proportion of milk producers by district and technical efficiency (TE) class.

Similarly, the proportion of milk producers scoring more than $90 \%$ TE is relatively higher in Kilosa (27\%) and Lushoto (24\%). The modal technical efficiency class is higher, 80 to $90 \%$, in Handeni and the same range (70-80\%) for the other districts (Kilosa, Mvomero, and Lushoto).

The results in Table 3 present the characteristics of milk-producing households in Tanzania, subdivided by TE class. The F statistics show that milk-producing households falling into the three technical efficiency classes ${ }^{7}$ have significantly different characteristics in terms of their ownership of small ruminants, their breeding and veterinary expenditure, their training, and their technical efficiency scores. Farmers who additionally engage in other agricultural activities such as small stock production can, when necessary, access cash quickly from their sales (Bahta et al. 2015), and this cash could be mobilized to cover farm input expenses.

This assertion is strengthened by the finding in Table 3, which shows a four times higher ownership of small ruminants by farms with technical efficiency scores above $65 \%$. The average number of small ruminants owned by the three technical

\footnotetext{
7 Class $1=$ Technical efficiency $<65 \%$ (approximately $10 \%$ of sample-lowest scoring); Class $2=$ Technical efficiency $=$ or $>65<95 \%$; and Class $3=$ Technical efficiency $=$ or $>95 \%$ (approximately $10 \%$ of sample- highest scoring).
} 
Fig. 5 District 1 (Kilosa, $N=63$; cumulative proportion of sampled dairy farmers above $90 \%$ technical efficiency $=27 \%$; modal class $=70-80 \%$ )

Fig. 6 District 2 (Mvomero, $N=192$; cumulative proportion of sampled dairy farmers above $90 \%$ technical efficiency $=18 \%$; modal class $=70-80 \%$ )
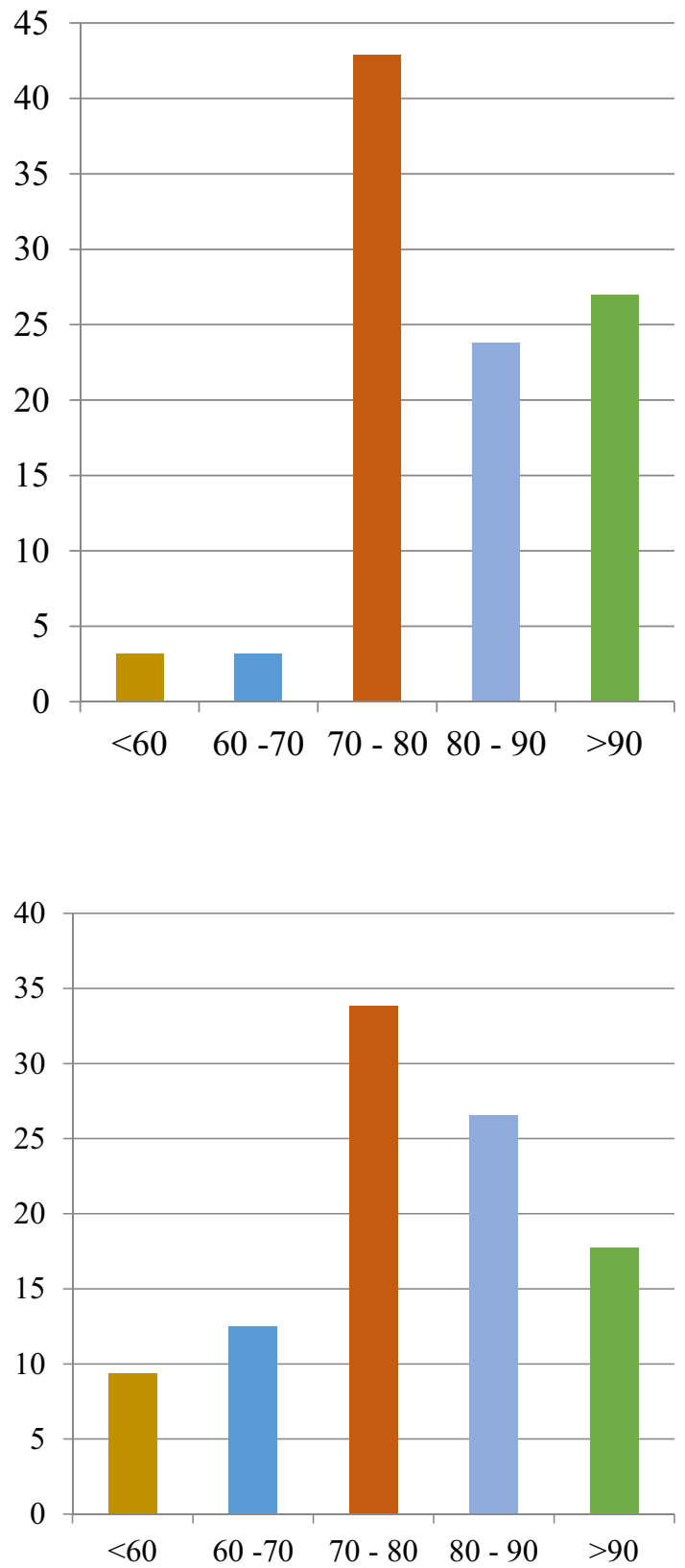

efficiency classes are significantly different and relatively higher (1.94 TLU) for the milk-producing farms belonging to $\mathrm{TE}$ class 2 ( $\mathrm{TE} \geq 65 \%$ and $<95 \%$ ) followed by class 3 (TE $\geq 95 \%$ ), who own on average about $1.81 \mathrm{TLU}$ small ruminants. 
Fig. 7 District 3 (Lushoto, $N=121$; cumulative proportion of sampled dairy farmers above $90 \%$ technical efficiency $=24 \%$; modal class $=70-80 \%$ )

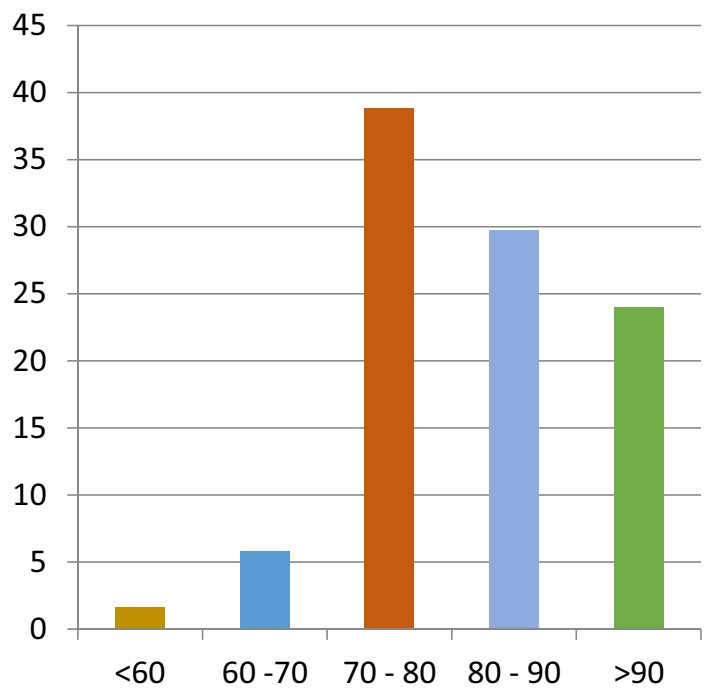

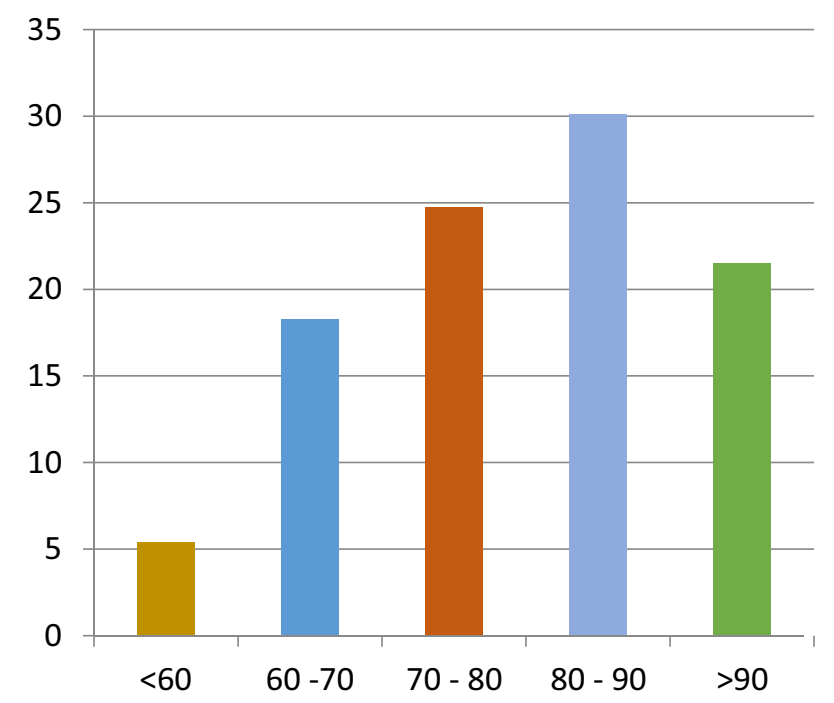

Fig. 8 District 4 (Handeni, $N=93$; cumulative proportion of sampled dairy farmers above $90 \%$ technical efficiency $=22 \%$; modal class $=80-90 \%$ )

In line with the findings in Table 2, the total veterinary and breeding expenditure, which is an indicator of the magnitude of veterinary inputs used and breeding technologies accessed, increases with an increase in technical efficiency. Such expense for TE class 3 milk-producing farms (TE scores higher than 95\%) is approximately 3.5 and 4 times higher than those farms in TE class 2 and 1, respectively. Similarly, the overall proportion of milk producers who received training is about $10 \%$, but 
they represent $88.8 \%$ and $20 \%$ of the farmers that achieved an efficiency score of above $65 \%$ and $95 \%$, respectively.

In terms of overall efficiency analysis, Table 3 also shows that the majority (78.5\%) of milk producing households have technical efficiency scores between 65 and $95 \%$, with their average at $80.2 \%$. About $11.2 \%$ of the farm households scored a technical efficiency of more than $95 \%$, and the rest of the farm households have technical efficiency of less than $65 \%$.

The total average technical efficiency is about $79.88 \%$, implying that there is still considerable scope to improve dairy production in Tanzania, under the current production and input mix and technology and management: by up to $20.12 \%$ of the total potential. For those milk producers with a technical efficiency score of less than $65 \%$, such scope of improvements extends to $40.82 \%$.

We find that variables associated with commercialization play a substantial role both in the production function and in the explanation of milk producer household efficiency. In the production function, we observe that parameter estimates for commercialization indicators (numbers of crossbred cows and selected expenditure values) are smaller than for more technical variables such as scale. For the determinants of efficiency, however, the parameter estimate for an indicator of commercialization (group membership in model 1 and commercialization index dummy in model 2) had the most significant magnitude of any in the analysis.

\section{Conclusion and Recommendations}

This study employs SFA to evaluate TE and its determinants in Tanzania's milkproducing households. The inference drawn for the study then refers to supporting actions to mobilize commercialization among such households.

Our results support much existing work to show that, assuming milk producers' rationality, increasing the numbers of cattle, cows, and crossbreeds, and use of additional veterinary and feed inputs all would increase productivity. Our analysis emphasizes the role to be played by behavior change, rather than stand-alone management change involving scale, technology, or organization, in implementing such change. The significance and magnitude of estimates of the importance of the indicators of commercialization that we develop appear throughout the analysis suggesting that technical and organizational change toward market orientation is needed.

Our sample of 469 farms exhibit an average TE estimated at $80 \%$, which suggests that there is still room to improve dairy production in milk-producing farms in Tanzania by about $20 \%$. Moving to value chain influences, the estimated inefficiency effects of the stochastic frontier model show that credit access, training, group membership, and female household labor would improve technical efficiency (reduce inefficiency). In contrast, non-cattle income would reduce efficiency in milk production in Tanzania. These results suggest the importance of actions beyond those of the individual milk producers. By convention, such calls are made for government action. However, our analysis and reasoning extends to facilitation actions and partnerships of actors in the value chain and beyond in order to advance elements of commercialization. 
There is a need to enhance access to dairy production inputs and services (feed, veterinary, breeding, training, and credit services) for dairy farmers. To an extent this embodies changes in organization, marketing and service content and orientation, and credit availability. Although future research would productively examine factors affecting uptake of such services, the current study has identified their uptake as a major determinant of productivity and hence advocates for accelerated access. Further, increases in productivity will have feedback effects in terms of economies of scale-particularly milk volumes-and its effect on unit costs, which our study did not investigate but are essential for future research.

We also recommend strengthening credit provision, possibly using local initiatives like SACCOs (Savings and Credit Co-operative Societies) or VICOBA (Village Community Banks) to provide capital to milk-producing households that would facilitate access to better production technologies, inputs, and markets. For larger-scale investments (inherent in crossbreeding or transforming access to inputs or markets), we advocate improving access to formal banks or by enabling checkoff (retained milk payments) systems and innovation in collateral recognition for milk producers. In this way, the commercialization offers both direct (via market access) and indirect (via the utilization of market transactions) roles in increasing productivity.

Our results highlight the role of training in improving productivity. The congruity of the effects of training with those of developmental actions listed above further magnifies the role of training in the commercialization of milk producers. Although conventional thinking on public goods would support government provision of training, other options are available. The options include enlistment of dairy processing and input provision actors, and channeling of training and technology via small-scale supported ventures_-such as seen in Business Development Services and NGO actions. This illustrates a further potential synergy between commercialization and enhanced productivity.

We identify a positive influence on productivity of membership of a producer group. This effect has been little examined in reviewed research, and yet supports much development impetus for commercialization. Future research should identify the mechanism of this impact, for example by examining the form, role, and size of producer groups for their influence on productivity, as well as that of the specific aspects of commercialization (reduced transaction costs, changed marketing practice, mode of contracting, and others). Moreover, producer groups provide a potential organizational form for commercialization actions and the accelerated information and material flows that it embodies. Our study confirms the previously observed importance of women in dairy production and marketing reported by others, but extends this knowledge to include women's positive influence on productivity. Women's reported concentration of dairy-related effort on marketing predisposes to group action in marketing and input supply due to women's social networks at a micro-level. Although there was some attempt in the past, future research should address this subject. At a grander scale, the extent to which commercialization led or facilitated by women generates better nutritional and social outcomes than does that led by men. 
Finally, we recommend any policy efforts aimed at creating an efficient tie between the farm sector and the market will improve the performance of dairy production. Hence, policy measures directed at increasing the market participation rate of farmers, by providing information and other market-related support services, will significantly contribute to improvements in agricultural productivity.

Acknowledgements This study was conducted as part of and funded by, the CGIAR Research Program on Livestock. We thank all donors that globally support our work through their contributions to the CGIAR system. The assistance and collaboration of local partners in Tanzania is gratefully acknowledged, as is the two anonymous reviewers of this journal. The opinions expressed here belong to the authors, and do not necessarily reflect those of livestock CRP or CGIAR.

\section{Compliance with Ethical Standards}

Conflict of interest On behalf of all authors, the corresponding author states that there is no conflict of interest.

Open Access This article is licensed under a Creative Commons Attribution 4.0 International License, which permits use, sharing, adaptation, distribution and reproduction in any medium or format, as long as you give appropriate credit to the original author(s) and the source, provide a link to the Creative Commons licence, and indicate if changes were made. The images or other third party material in this article are included in the article's Creative Commons licence, unless indicated otherwise in a credit line to the material. If material is not included in the article's Creative Commons licence and your intended use is not permitted by statutory regulation or exceeds the permitted use, you will need to obtain permission directly from the copyright holder. To view a copy of this licence, visit http://creativecommons.org/licenses/by/4.0/.

\section{References}

Aigner, D., K. Lovell, and P. Schmidt. 1977. Formulation and estimation of stochastic frontier production function models. Journal of Econometrics 6 (1): 21-37.

Bahta, S., B. Derek, P. Malope, and K. Hikuepi. 2015. A Stochastic Meta-frontier analysis of the determinants of technical efficiency. An application to Botswana's different beef farm systems. Paper presented at the 29th International Conference of Agricultural Economists (ICAE), 8-14 Aug, Milan, Italy.

Bahta, S., and P. Malope. 2014. Measurement of competitiveness in smallholder livestock systems and emerging policy advocacy an application to Botswana. Food Policy 49 (2): 408-417.

Baker, D., J. Cadilhon, and W. Ochola. 2015. Identification and analysis of smallholder producers' constraints: Applications to Tanzania and Uganda. Development in Practice 25 (2): 204-220. https:// doi.org/10.1080/09614524.2015.1007924.

Battese, G.E., D.S.P. Rao, and C. O’Donnell. 2004. A metafrontier production function for estimation of technical efficiencies and technology gaps for firms operating under different technologies. Journal of Productivity Analysis 21 (1): 91-103.

Bauer, P.W. 1990. Recent developments in the econometric estimation of frontiers. Journal of Econometrics 46 (1-2): 39-56.

Bravo-Ureta, B.E., and A.E. Pinheiro. 1993. Efficiency analysis of developing country agriculture: A review of the frontier function literature. Agricultural and Resource Economics Review 22 (1): 88-101.

Brummer, B., and J.P. Loy. 2000. The technical efficiency impact of farm credit programmes: A case study in Northern Germany. Journal of Agricultural Economics 51 (3): 405-418.

Chirwa, E.W. 2007. Sources of technical efficiency among smallholder maize farmers in Southern Malawi (No. RP_172 Keywords: smallholder maize farmers, technical efficiency, southern Malawi). Nairobi: African Economic Research Consortium. 
Coelli, T.J. 1995. 'Estimators and hypothesis tests for a stochastic frontier function: A Monte Carlo analysis. Journal of Productivity Analysis 6 (3): 247-268.

Coelli, T., D.S.P. Rao, C.J. O’Donnell, and G.E. Battese. 2005. An introduction to efficiency and productivity analysis, 2nd ed. Boston: Kluwer Academic Publishers.

Covarrubias, K., L. Nsiima, and A. Zezza. 2012. Livestock and livelihoods in rural Tanzania. A descriptive analysis of the 2009 National Panel Survey. Joint paper of the World Bank, FAO (Food Agriculture Organization of the United Nations), AU-IBAR, ILRI (International Livestock Research Institute), and the Tanzania Ministry of Livestock and Fisheries Development.

Delgado, C., M. Rosegrant, H. Steinfeld, S. Ehui, and C. Courbois. 1999. Livestock 2020: The next food revolution. Discussion Paper 28, International Food Policy Research Center, Washington, D.C.

Erkoc, T.E. 2012. Estimation methodology of economic efficiency: Stochastic frontier analysis vs. data envelopment analysis. International Journal of Academic Research in Economics and Management Sciences 1 (1): 1.

FAO. 2015. The economic lives of smallholder farmers: An analysis based on household data from nine countries. Rome.

FAO. 2019. The future of livestock in Kenya. Opportunities and challenges in the face of uncertainty. Rome

Gebremedhin, B., and M. Jaleta. 2010. Commercialization of smallholders: Does market orientation translate into market participation? Improving productivity and market success (IPMS) of Ethiopian Farmers Project Working Paper 22. Nairobi, Kenya, ILRI.

Gelan, A., and B. Muriithi. 2015. Examining returns to scale in smallholder dairy farms in East Africa. Quarterly Journal of International Agriculture 54 (3): 239-261.

Greene, W.H. 2003. Econometric analysis, 5th ed. New Jersey: Prentice-Hall.

Greene, W.H. 2008. The econometric approach to efficiency analysis. The Measurement of Productive Efficiency and Productivity Growth 1: 92-250.

Gyau, A., S. Franzel, M. Chiatoh, G. Nimino, and K. Owusu. 2014. Collective action to improve market access for smallholder producers of agroforestry products: Key lessons learned with insights from Cameroun's experience. Current Opinion in Environmental Sustainability 6: 68-72.

Huang, C.J., and J.T. Liu. 1994. Estimation of a non-neutral stochastic frontier production function. Journal of Productivity Analysis 5 (2): 171-180.

Hyuha, T.S. 2006. Profit efficiency among rice producers in Eastern and Northern Uganda. Ph.D. Thesis, Makerere University, Uganda.

Jondrow, J., C.K. Lovell, I.S. Materov, and P. Schmidt. 1982. On the estimation of technical inefficiency in the stochastic frontier production function model. Journal of Econometrics 19 (2-3): 233-238.

Katjiuongua, H. and S. Nelgen. 2014. Tanzania smallholder dairy value chain development: Situation analysis and trends ILRI Project Report. Nairobi, Kenya: ILRI.

Kodde, D.A., and F.C. Palm. 1986. Wald criteria for jointly testing equality and inequality restrictions. Econometrica 54: 243-1248.

Kolawole, O. 2006. Determinants of profit efficiency among small scale rice farmers in Nigeria: A profit function approach. Research Journal of Applied Sciences 1 (1): 116-122.

Kumbhakar, S.C., and L. Hjalmarsson. 1991. Estimation of technical efficiency and technical progress free from farm-specified effects: an application to Swedish dairy farms. Memorandum-Department of Economics, Gothenburg University, School of Economics and Legal Science (Sweden).

Laha, A. 2014. Technical efficiency in agricultural production and access to credit in west Bengal, India: A stochastic frontier approach. International Journal of Food and Agricultural Economics 1 (2): 53-64.

Latruffe, L. 2010. Competitiveness, productivity and efficiency in agricultural and agri-food sectors. OECD Food, Agriculture and Fisheries Papers, No. 30, OECD Publishing.

Makoni, N., R. Mwai, T. Redda, A. van der Zijpp, and A. van der Lee. 2013. White gold; Opportunities for dairy sector development collaboration in East Africa. Centre for Development Innovation, Wageningen UR (University \& Research centre). CDI report CDI-14-006. Wageningen.

Mester, Loretta J. 2003. Applying efficiency measurement techniques to central banks, Working Paper No. 03-13, Federal Reserve Bank of Philadelphia.

Meeusen, W., and J. Van Den Broeck. 1977. Efficient estimation from Cobb-Douglas production functions with composed error. International Economic Review 18: 435-444.

Murthy, K.V. 2002. Arguing a case for Cobb-Douglas production function. Review of Commerce Studies 20-21 (1): 75-91.

NIRAS. 2010. Survey on dairy products market in Tanzania. Rural Livelihood Development Company. Final report. 
Omondi, I., E.J.O. Rao, A.A. Karimov, and I. Baltenweck. 2017. Processor linkages and farm household productivity: Evidence from dairy hubs in East Africa. Agribusiness 33: 586-599. https://doi. org/10.1002/agr.21492.

Otieno, D.J., L. Hubbard, and E. Ruto. 2012. Determinants of technical efficiency in beef cattle production in Kenya. Paper presented at the International Conference of Agricultural Economists (ICAE), 18-24 Aug, Foz do Iguacu, Brazil.

Obwona, M. 2006. Determinants of technical efficiency differentials amongst small-and medium-scale farmers in Uganda: A case of tobacco growers, AERC research paper 152. Nairobi: African Economic Research Consortium.

Pingali, P.L. 1997. From subsistence to commercial production systems: The transformation of Asian agriculture. American Journal of Agricultural Economics 79: 628-634.

Pingali, P.L., and M.W. Rosegrant. 1995. Agricultural Commercialization and diversification: Processes and policies. Food Policy 20 (3): 171-185.

Rakipova, A.N., J.M. Gillespie, and D.E. Franke. 2003. Determinants of technical efficiency in Louisiana beef cattle production. Journal of ASFMRA Research and Case Studies 2003: 99-107.

Rao, E.J.O., I.A. Omondi, A.A. Karimov, and I. Baltenweck. 2016. Dairy farm households, processor linkages and household income: The case of dairy hub linkages in East Africa. International Food and Agribusiness Management Review 19 (4): 95-108.

Ravallion, M., and S. Chen. 2003. Measuring pro-poor growth. Economics Letters 78: 93-99.

Shapiro, B.I. 2017. Tanzania livestock master plan: Milk results for the sector analysis (2016-2031). https ://cgspace.cgiar.org/bitstream/handle/10568/81330/mz_forum_shapiro_may2017.pdf?sequence=1. Accessed 6 June 2017.

Russell, N.P., and T. Young. 1993. Frontier production functions and the measurement of technical efficiency. Journal of Agricultural Economics 34: 139-150.

Springer-Heinze, A. 2018. ValueLinks 2.0. Manual on sustainable value chain development, GIZ Eschborn, 2 volumes.

Stevenson, R.E. 1980. Likelihood functions for generalized stochastic frontier estimation. Journal of Econometrics 13: 57-66.

Swinnen, J.F.M., and M. Maertens. 2007. Globalization, privatization, and vertical coordination in food value chains in developing and transition countries. Agricultural Economics 37: 89-102.

Tirkaso, W., and S. Hess. 2018. Does commercialization drive technical efficiency improvements in Ethiopian subsistence agriculture? African Journal of Agricultural and Resource Economics 13 (1): 44-57.

Twine, E., and H. Katjiuongua. 2015. Farm-level and consumption responses to improved efficiency of Tanzania's Informal Dairy Value Chain. 2015 AAEA \& WAEA Joint Annual Meeting, July 26-28, San Francisco, California 200329, Agricultural and Applied Economics Association.

Twine, E.E., E.J.O. Rao, and I. Baltenweck. 2019. Are technology adoption and collective action important in accessing credit? Evidence from milk producers in Tanzania. The European Journal of Development Research 31: 388-412. https://doi.org/10.1057/s41287-018-0158-z.

von Braun, J. 1995. Agricultural commercialization: Impacts on income and nutrition and implications for policy. Food Policy 20 (3): 87-202.

Wang, H.J., and P. Schmidt. 2002. One-step and two-step estimation of the effects of exogenous variables on technical efficiency levels. Journal of Productivity Analysis 18 (2): 129-144.

Publisher's Note Springer Nature remains neutral with regard to jurisdictional claims in published maps and institutional affiliations. 


\section{Affiliations}

\section{Sirak Bahta ${ }^{1}\left[\right.$ ] Amos Omore ${ }^{2}$. Darek Baker ${ }^{3} \cdot$ Iheanacho Okike $^{4}$. Berhanu Gebremedhin ${ }^{5}$. Francis Wanyoike ${ }^{1}$}

Amos Omore

a.omore@cgiar.org

Darek Baker

abaker33@une.edu.au

Iheanacho Okike

i.okike@cgiar.org

Berhanu Gebremedhin

b.gebremedhin@cgiar.org

Francis Wanyoike

f.wanyoike@cgiar.org

1 International Livestock Research Institute, 30709 Old Naivasha Road, Nairobi, Kenya

2 International Livestock Research Institute (ILRI), Dar es Salaam, Tanzania

3 UNE Business School, University of New England, Armidale, NSW 2351, Australia

4 International Institute of Tropical Agriculture (IITA), Ibadan, Nigeria

5 International Livestock Research Institute (ILRI), Addis Ababa, Ethiopia 